\title{
NAMA MUHAMMAD DALAM AL-QUR'AN DAN INJIL
}

\author{
Indra Latif Syaepu \\ indrastainkediri@gmail.com \\ Dosen Ushuluddin STAIN Kediri
}

\begin{abstract}
Abstrak:
Al-Qur'an adalah kitab suci agama Islam yang diyakini sebagai kebenaran mutlak, baik yang bersifat doktrin, kisah masa lalu atau masa depan. Dalam al-Qur'an dikabarkan bahwa kedatangan Muḥammad sudah dijelaskan dalam kitab-kitab suci sebelumnya. Untuk itu, tulisan ini akan mengkombinasikan antara prediksi yang ada dalam Injil dan pernyataan al-Qur'an. Penulis menggunakan studi komparatif sedangkan kesimpulannya adalah terdapat kesesuaian antara pernyataan alQur'an dengan berita yang dibawa oleh kitab-kitab terdahulu.
\end{abstract}

Kata kunci: Muḥammad, al-Qur'an, Injil.

\section{A. Latar Belakang}

Muḥammad adalah nama yang menyita perhatian dunia baik oleh muslim maupun non-muslim karena Muhammad adalah orang yang paling berpengaruh di dunia. ${ }^{1}$ Muslim pada umumnya menaruh rasa kagum terhadap pribadi Muhammad saw. karena kepribadian dan sikapnya yang sangat terpuji. Hal ini dapat dikatakan wajar memang doktrin yang diterima oleh seorang muslim sejak kecil mengharuskan iman dan fanatik kepada Muhammad saw.

Sementara itu, bagi non-muslim - terutama Kristen - nama Muhammad cukup mmebuat resah. Sebab, agama yang di bawanya menjadi saingan terberat saat ini atau bahkan dapat mengalahkannya

1 Michael H. Hart The 100, The Top Hundred or Greastest Hundred in History/seratus orang yang paling besar sepanjang sejarah. Hart menobatkan nabi Muhammad sebagai nomintor tertinggi. Ahmad Deedat, The Choice. Jakarta: Pustaka Al-Kautsar, 1999, 119120.

Spiritualis, vol. 4, no. 1, Maret 2018

ISSN: $2442-5907 \mid 50$ 
di kemudian hari. ${ }^{2}$ Tidak jarang bagi orang yang anti dengan Muhammad, mereka melancarkan serangan dan juga tuduhan demi membela ideologi yang di diyakininya. Misalnya Muḥammad adalah byper sex, epilepsy atau bahkan crazy.

Banyak buku sejarah yang menulis tentang kepribadian Muhammad, baik dari masa kecil hingga wafat atau bahkan ada yang menuliskannya sejak zaman jahiliyah Arab hingga para keturunannya. ${ }^{3}$ Hal ini dirasa sangat wajar sebab Muhammad adalah sosok yang sangat penting dalam sejarah manusia. Orang yang anti terhadap Muhammad akan menuliskan karya yang memberikan citra negatif terhadap Muhammad. Akan tetapi orang yang fanatik kepadanya akan menuliskan secara berlebihan.

Sementara itu, pandangan apapun tentang Muhammad, baik oleh orang yang fanatik ataupun oleh orang yang antipati, penting kiranya dikaji sosok seorang Muhammad dalam pandangan alQur'an. Sebab, saat ini cukup marak kajian tafsir yang berbasis tema, arena Muhammad adalah orang terpenting dalam kajian Islam, baik sejarah, hadis, hukum dan sebagainya. Untuk itu penelitian ini akan membahas tentang nama Muḥammad yang di gambarkan oleh alQur'an. Sebab, al-Qur'an memberikan informasi bahwasannya kedatangan sosok Muhammad telah di prediksikan oleh kitab-kitab terdahulu.

B. Mekanisme Tafsir Tematik

Sebelum membahas lebih lanjut mengenai tafsir tematik dalam penelitian ini, terlebih dahulu penulis antarkan sekilas mengenai mekanisme tafsir tematik. Hal ini diharapkan agar tidak terjadi kesalah-pahaman mengenai metode yang di gunakan oleh penulis dalam mengkaji suatu tema. Adapun mekanisme tafsir tematik menurut al-Farmawi adalah sebagai berikut: Pertama, menghimpun ayat yang sesuai dengan judul dan kronolagis urutan

2 Abdur Rohman, Islam Akan Menang: Analisa Kemenangan Islam di Masa Depan. Kediri, Parafrasa dan Santri Salaf Press, 2013.

${ }^{3}$ Husain Haekal, Sejarah Muhammad saw. Jakarta, Litera Antarnusa, 2011. 
turunnya. Kedua, menelusuri asbāb al-nu₹ūl suatu ayat (jika ada). Ketiga, meneliti dan mencermati kata-kata atau kalimat yang menjadi kata kunci lalu mengkajinya dari berbagai aspek baik dari segi bahasa, munasabät dan sebagainya. Keempat, mengkaji pemahaman suatu ayat tersebut dari beberapa mufasir baik yang klasik mapun kontemporer. Kelima, semua di bahas dengan tuntas dengan penalaran yang objektif melalui kaidah-kaidah tafsir yang mu'tabar serta di dukung dengan argument yang kuat baik dari al-Qur'an itu sendiri, hadis, ataupun dengan fakta sejarah. ${ }^{4}$

Dalam penelitian kali ini, nama Muhammad di sebutkan sebanyak 4 kali sedangkan nama Aḥmad disebutkan sekali. ${ }^{5}$ Adapun perinciaannya sebagai berikut; $\bar{A}$ li Imrān [3]: 144, al-Aḩzāb [33]: 40, al-Fath [48]: 29, Muhammad [47]: 2 dan al-Ṣaf [61]: 6. Untuk itu, penafsiran yang akan dilakukan oleh penulis akan berkutat dalam lima ayat tersebut dan penambahan ayat dibutuhkan manakala memperkuat kelima ayat di atas. Dari kelima ayat tersebut hanya satu yang menyebutkan nama Ahmad. Untuk itu, pembahasan nama Ahmad ini akan penulis letakkan setelah pembahasan nama Muhammad.

C. Muhammad Rasul Allah

1. Ali Imrān [3]: 144

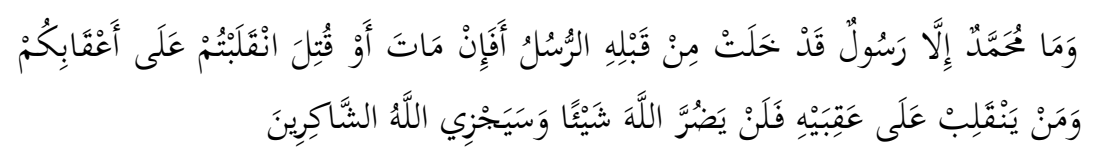

Muhammad tidak lain hanyalah seorang rasul, telah berlalu sebelumnya beberapa rasul. Apakah jika ia wafat atau dibunuh, kamu berbalik ke belakang (murtad)? Barangsiapa yang berbalik

4 'Abd al-Hayy al-Farmawy, al-Bidayah fí al-Tafsì al-Maudhu'i. Mesir: Maṭaa'at alHaḍarāt al-'Arabiyah, 1977.

5 Muhammad Fu'ad 'Abd al-Bāqi. Al-Mu'jam al-Mufahras li Alfäz al-Qur'an al-Ažìn. Kairo: Dār al-Ma’àrif, 1119, 217 
ke belakang, maka ia tidak dapat mendatangkan madarat kepada Allah sedikitpun dan Allah akan memberikan balasan kepada orang-orang yang bersyukur. ${ }^{6}$

Ayat ini ditafsirkan oleh Ibn 'Abbās's sebagai berikut:

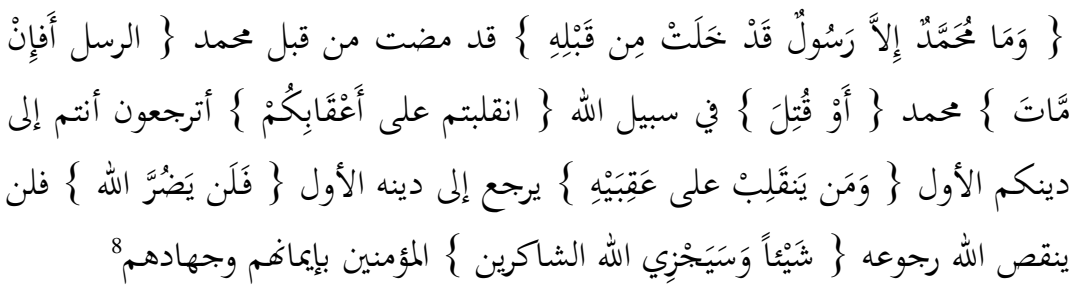

Muhammad tidak lain hanyalah seorang rasul. Telab berlalu beberapa rasul, maksudnya adalah telah berlalu sebelum Muhammad. beberapa rasul. Apakah jika ia wafat. Maksudnya disini adalah Muhammad. Atau terbunuh dijalan Allah kamu sekalian akan berbalik ke belakang, maksudnya adalah apakah kamu sekalian akan

${ }^{6}$ Departemen Agama Republik Indonesia, Al-Qur'an dan Terjemabnya, QS. Āli 'Imrān [3]: 144 .

7 Ibn 'Abbās lahir di Makkah tahun ke-3 sebelum hijtah. Mungkin karena masih sepupu kerabat dekat Nabi, pada saat ia lahir, Nabi saw. mengunjunginya atau dalam istilah Jawa di sebut dengan jagong bayi. Dan Ibn 'Abbās wafat pada usia 70 tahun tepatnya pada tahun $68 \mathrm{H}$. di Țäif. Ibn Abbās tergolong mufasir terkemuka di kalangan sahabat Nabi. Kehebatan Ibn 'Abbās dalam dunia tafsir dapat di analisa dari berbagai sudut. Diantaranya adalah do'a Rasulullah Allabumma 'allimbu al-kitäb wa alhikmah (Ya Allah semoga engkau cerdaskan ia dalam urusan al-Kitāb dan hikmah). Kesaksian lain juga di nyatakan oleh para sahabat senior, Ibn Mas'ūd berkata nima turjumān al-Qur'an, Ibn 'Abbäs (sebaik-baik penterjemah/mufsir al-Qur'an adalah Ibn 'Abbās), Ali bin Abī Ṭălib berkata: kaannama yanžuru ila al-gbaib min sitr al-raqiq (Tafsir Ibn 'Abbās, bagaikan menerawang terhadap hal-hal ghaib di balik tirai yang lebut). Bahkan Umar bin Khatțāb berkata a'lamu ummati Muhammad bima nuzila 'ala Muhammad (Ibn 'Abbās adalah umat Muhammad yang lebih mengerti tentang yang di turunkan kepada Muhammad). Lihat selengkapnya, Abdur Rohman, Tafsir Sababat: Fakta Sejarah Penafsiran al-Qur'an Ala Sababat Nabi. Kediri, Parafrasa, 2015, 79-80.

${ }^{8}$ Yunsabu ila al-Ṣahabah 'Abd Allah Ibn 'Abbās, al-Miqbäs min Tafsìr Ibn 'Abbäs (alMaktabah al-Shāmilah al-Iṣdār Thāni), QS. Ali Imrān [3]: 144. 
kembali kepada agamamu semula? Barangsiapa yang berbalik ke belakang maksudnya adalah kembali kepada agamanya yang awal, hal itu tidak akan mendatangkan madarat sedikitpun kepada Allah maksudnya adalah berpalingnya mereka tidak akan berdampak kepada Allah dan Allab akan memberikan balasan bagi orang-orang yang bersyukur maksudnya adalah orang-orang mukmin yang teguh dengan iman dan jihadnya.

Sementara dalam pandangan Ibn Kathirr ${ }^{9}$ ayat ini menjelaskan bahwa seorang Muhammad adalah seorang manusia yang sangat mungkin apabila terbunuh di medan perang. Dalam tafsirnya di jelaskan bahwa ada seseorang Muhajirin yang mengabarkan kematian Muhammad di medan perang (Uhud), lalu turunlah ayat ini. ${ }^{10}$ Keterangan yang di paparkan oleh Ibn Kathir di atas di perkuat oleh sebuah hadis dari riwayat Bukhari bahwasannya pada saat berkecamuk perang Uhud tersiar kabar bahwa Nabi saw. meninggal dunia sehingga membuat suasana memanas, bahkan ada yang bermaksud meminta perlindungan kepada Abū Sufyān. sementara itu, orang-orang munafik mengatakan bahwa kalau Muhammad itu seorang nabi, tentulah dia tidak akan mati. Lalu turunlah ayat ini sebagai bantahan terhadap prasangka kaum munafik dan juga untuk menenteramkan umat Islam. ${ }^{11}$

Ayat ini juga menjadi terapi sosial kepada Umar bin Khatțāb pada saat mendengar kematian Rasul saw. Umar marah pada saat tersiar kabar bahwa Nabi meninggal dunia. Umar

9 'Imād al-Dīn Abū al-Fidā' Ismā̄îl bin 'Amr al-Baṣri al-Qarshi al-Dimashqi alMashhür bi Ibn Kathir, beliau lahir pada tahun 700 dan wafat pada tahun $774 \mathrm{H}$. Kitab tafsir yang ditulis berjudul Tafsir al-Qur'an al-'Ažim, namun juga terkenal dengan sebutan Tafsir Ibn Kathïr. Kitab ini terdiri dari 8 juz. Berdasarkan namanya, beliau berasal dari Damaskus, Siria.

10 'Imād al-DĪn Abū al-Fidā' Ismā̄ìl bin 'Amr al-Bașri al-Qarshi al-Dimashqi alMashhūr bi Ibn Kathir, Tafsìr al-Qur'ān al-'Ažim. al-Maktabah al-Shāmilah al-Iṣdār Thāni.

11 Muhammad bin Ismā̄̄il bin Ibrāhim bin al-Mughīrah al-Bukhāri, al-jāmi' al-Ṣaḅịh. Kairo: Dār al-Shu'ab, 1987, Bab jihad. 
berkata mengangkat pedang dan berkata 'Barangsiapa yang berkata bahwa Muhammad telah wafat, akan ku penggal lehernya.' Untuk meredam kemarahan Umar tersebut, Abü Bakar membacakan ayat di atas wa mā Muhammadun illa al-rasūl qad khalat min qablibi al-rasül. mendengar ayat tersebut sentak pedang yang ada di tangan Umar terjatuh dan iapun tersungkur seakan tak percaya dengan kenyataan tersebut. ${ }^{12}$

2. Al-Aḥzāb [33]: 40

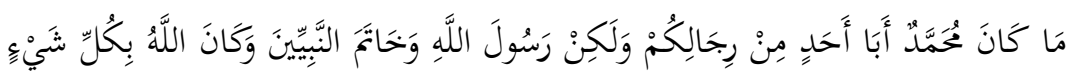

عَلِيمًا

"Muhammad itu bukanlah bapak seorang laki-laki diantara kamu tetapi dia adalah Rasulullah, penutup para nabi dan Allah Maha Mengetahui segala sesuatu." ${ }^{13}$

Menurut al-Baghawi, penafsiran ayat di atas sebagai berikut:

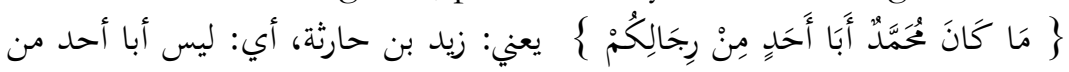

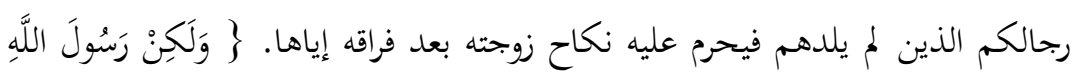

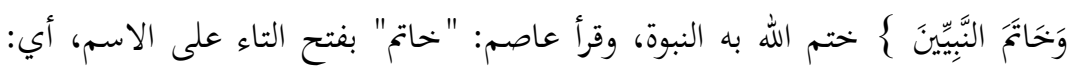
آخرهم، وقرأ الآخرون بكسر التاء على الفاعل، لأنه ختم به النبيين فهو خاتمهم.

Maksud ayat Muhammad bukanlah ayah salah satu dari kamu sekalian. Yang dimaksud adalah Zaid bin Harithah. Ia adalah anak angkat Nabi yang menceraikan istrinya. Itu artinya seorang anak

${ }^{12}$ Lihat, al-Jumanatul Ali: al-Qur'an dan Terjemahnya, 69-70. Saḅị Bukbäri (al-Maktabah al-Shāmilah al-Iṣdār Thāni) juz 5, 8, nomor hadis 3668.

13 Departemen Agama Republik Indonesia, al-Qur'an dan Terjemabnya, QS. Al-Aḥ̄āb [33]: 40.

14 Al-Ḥusain bin Mas'ūd bin Muhammmad bin al-Farā' al-Shāfi'i al-Baghawi, Ma'ālim al-Taņ̃ĭl, (al-Maktabah al-Shāmilah al-Iṣdār Thāni). 
Spiritualis, vol. 4, no. 1, Maret 2018|56

angkat hukumnya tidak sama dengan anak kandung dan juga istri Zaid yang di ceraikan tersebut dapat di nikahi oleh Nabi. Sementara dalam tafsir ini dijelaskan bahwasannya Nabi Muḥammad hanyalah seorang rasul dan menjadi penutup para nabi Allah.

Pada kata khätam ada dua qira'ah (bacaan). Menurut bacaan pertama dari 'A Ashim, ayat tersebut di baca dengan fathah-nya ta' (khäam) sehingga berkedudukan sebagai isim. Sedangkan menurut bacaan imam yang lain kata tersebut dapat di baca dengan kasrahnya ta' (khätim) sehingga berkedudukan menjadi fa'il. Dibaca dengan menggunakan ḩarakat apapun substansinya tidak akan berbeda jauh. Sebab Nabi Muhammad dapat dikatakan sebagai orang yang menjadi penutup para nabi, juga sekaligus menjadi pelaku (fa'il).

Sementara itu, al-Qurtubi ${ }^{15}$ menjelaskan bahwa ayat di atas memiliki sebab turun. Ayat tersebut turun berkenaan dengan desas-desus tentang pernikahan Nabi dengan Zainab. Tersiar kabar bahwa Nabi menikahi istri anaknya sendiri, Zaid bin Harithah. Lalu turunlah ayat ini sebagai klarifikasi dan penetapan hukum. ${ }^{16}$

Ayat ini juga diperkuat dengan ayat lain dalam surah alAhyāb [33]: 50. Ayat ini sesungguhnya juga mempertegas bahwa dalam Islam diperbolehkan untuk menikahi mantan istri anak angkat. Jadi, motif utama dalam pernikahan ini adalah ketetapan hukum. Nabi adalah sumber hukum kedua setelah al-Qur'an, sehingga ayat dan praktik Nabi mempertegas bahwa mantan istri anak angkat boleh di nikahi.

15 Nama lengkap al-Qurtubi adalah Muhammad bin Ahmad bin Abi Bakr bin Farh Abū 'Abd Allāh al-Qurțubi, al-Jāmi' al-Abkēm al-Qur'an, atau sering kali disebut dengan Tafsir Qurtubi. Sesuai dengan namanya, pengarang kitab ini berasal dari Cordova Sapnyol. Kitab ini memuat semua semua surat al-Qur'an dan terdiri dari 20 jilid.

${ }^{16}$ Muḥammad bin Aḥmad bin Abī Bakr bin Farḥ Abū 'Abd Allāh al-Qurțubi, al-Jāmi' al-Abkèm al-Qur'an (al-Maktabah al-Shāmilah al-Iṣdār Thāni). 
3. Al-Fath [48]: 29

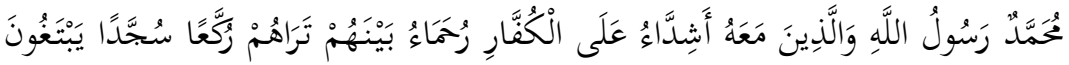

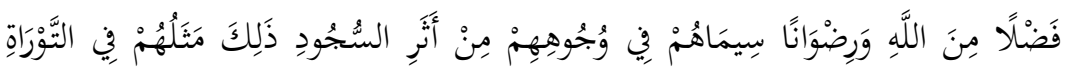

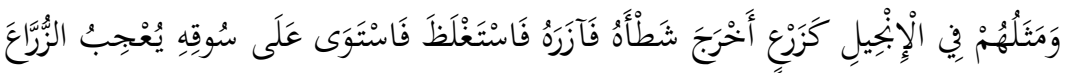

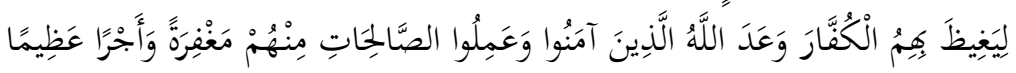
Muhammad itu adalah utusan Allah dan orang-orang yang bersama dengan dia adalah keras terhadap orang kafir, tetapi berkasih sayang terhadap sesama mereka. Kamu lihat mereka ruku' dan sujud mencari karunia Allah dan keridhaan-Nya, tandatanda mereka tampak pada muka mereka dari bekas sujud. Demikianlah sifat-sifat mereka dalam Taurat dan Injil yaitu seperti tanaman yang mengeluarkan tunasnya, maka tunas itu menjadikan tanaman itu kuat lalu menjadi besarlah dia dan tegak lurus di atas pokoknya; tanaman itu menyenangkan hati penanampenanamnya karena Allah hendak menjengkelkan hati orangorang kafir. Allah menjanjikan kepada orang-orang yang beriman dan mengerjakan amal saleh di antara mereka ampunan dan pahala yang besar. ${ }^{17}$

Menurut al-Samarqandi, nabi Muhammad adalah utusan Allah dan orang yang bersamanya adalah Abu Bakar keras terhadap orang kafir adalah Umar berkasih sayang terhadap sesama adalah Uthmān kalian melihat mereka ruku' dan sujud adalah Ali bin Abī Tălib mencari karunia Allab dan keridhaan-Nya adalah Zubair dan 'Abd al-Raḥmān bin 'Auf, tanda-tanda mereka tampak pada muka mereka dari bekas sujud, maksudnya adalah sebuah pertanda, bahwa terdapat warna kuning di wajah mereka. Demikianlah sifat-sifat mereka dalam Taurat dan Injil yaitu sebuah ramalan akan keadaan mereka dalam Taurat dan Injil.

Yaitu seperti tanaman yang mengeluarkan tunasnya. Pada kata shat'ahu dalam ayat ini menurut bacaan Ibn Kathir dan Ibn 'Āmir

${ }^{17}$ Departemen Agama Republik Indonesia, al-Qur'an dan Terjemabnya, QS al-Fath [48]: 
adalah dengan fathah-nya shin dan nasab-nya ta' (shata'abu) sedangkan yang lain membaca dengan fahah-nya shin dan jarmnya ta' (shat'ahu) yang memiliki makna sama, yaitu tumbuhan bertunas. Sedangkan pada lafad fa'azarahu menurut bacaan Ibn 'Āmir tanpa di baca mad (fa'azarabu) sedangkan yang lain membaca dengan panjang ( $f a$ az̧ärabu) di baca dengan panjang atau pendek tidak mempengaruhi terhadap makna, sebab makna dari keduanya adalah sama.

Maka tunas itu menjadikan tanaman itu kuat lalu menjadi besarlah dia dan tegak lurus di atas pokoknya; tanaman itu menyenangkan hati penanam-penanamnya. Ayat ini dalam pandangan al-Samarqandi adalah sebagai perumpamaan sahabat-sahabat Nabi yang tumbuh berkembang dan saling menguatkan. Dakwah Nabi di terima oleh Abu Bakar, Umar dan kemudian satu-persatu dari sahabat yang lain sehingga membuat Nabi berbahagia.

Karena Allab bendak menjengkelkan hati orang-orang kafir. Maksudnya adalah orang-orang kafir sangat jengkel melihat banyaknya orang yang masuk Islam, terutama masuknya orangorang kuat seperti Umar, Țalhah dan Zubair dan juga karena kekayaan mereka.

Allah menjanjikan kepada orang-orang yang beriman dan mengerjakan amal saleh di antara mereka ampunan dan pabala yang besar. Maksud dari ayat ini adalah Allah menyediakan ampunan bagi orang-orang yang beriman meskipun dahulunya ia orang kafir dan juga menjanjikan surga, bahkan ada sebuah riwayat yang menyatakan bahwa 'Barangsiapa yang membaca surat al-Fath ia bagaikan mati shahid saat fatḥ makkah bersama dengan Rasulullah. ${ }^{18}$

${ }_{18}$ Nasr bin Muhammad bin Ahmad al-Samarqandi, Bạ̣r al-Ulüm (al-Maktabah alShāmilah al-Iṣdār Thāni). 
D. Jaminan Allah ketika iman pada Muḥammad

Dalam Surah (Muhammad [47]: 2, Allah berfirman:

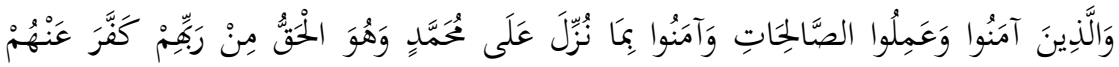

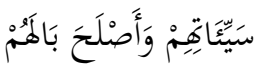

Orang-orang yang beriman kepada Allah dan mengerjakan amal saleh serta yang beriman (pula) terhadap yang di turunkan kepada Muhammad, itulah yang hak dari Tuhan mereka, Allah menghapuskan kesalahan-kesalahan mereka dan memperbaiki keadaan mereka. ${ }^{19}$

Penafsiran ayat di atas menurut Mujāhid seorang pakar tafsir dari kalangan tabi'in adalah, aslaḥa bālahum yang bermakna memperbaiki keadaan mereka. ${ }^{20} \mathrm{Al}-Z_{\text {Zuhaili }}{ }^{21}$ dalam tafsir al-Wasit menjelaskan sebab turunnya ayat di atas dan sebelumnya, yaitu ayat 1-2 dari riwayat Ibn 'Abbās bahwasannya ayat ini turun kepada penduduk Makkah dan kaum Anșār. Ayat pertama turun kepada penduduk Makkah yang kafir sedangkan ayat kedua turun kepada kaum Anșār yang mengerjakan amal saleh. ${ }^{22}$ Sebab turun ayat di atas juga dikuatkan oleh penafsiran Ibn 'Atiyah' yang menyatakan bahwa

${ }^{19}$ Departemen Agama Republik Indonesia, al-Qur'an dan Terjemahnya, QS. Muhammad [47]: 2

${ }^{20}$ Abū al-Hajjaj Mujāhid bin Jabr al-Tābi'i al-Qarshi al-Makhzūmi, Tafsìr Mujāhid (alMaktabah al-Shāmilah al-Iṣdār Thāni), QS. 47: 2.

${ }^{21}$ Wahbah bin Muștafa al-Zuhaili, beliau lahir di pelosok kota Damaskus Suriah pada tahun 1351 H/ 1932 M. Ia memiliki dua karya tafsir. Yaitu Tafsir al-Munì fi al-Aqìdah wa al-Shari' at wa al-Manhaj dan Tafsir al-Wasit. Untuk tafsir al-Munir memiliki ciri khas dalam sitematikanya, yaitu pertama dari sisi i'rāb, lalu balaghah, mufradăt al-Lughawiyyah,

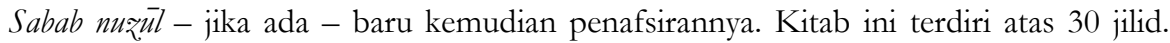
Sementara tafsir al-Wasit memiliki ciri khas tersendiri, yaitu beliau menjelaskan judul besarnya suatu ayat dan langsung di tafsirkan. Tafsir ini hanya berjumlah 3 jilid.

${ }^{22}$ Wahbah bin Muștafa al-Zuhaili, al-Tafsì al-W asịt. Damaskus: Dār al-Fikr, 1422), QS. 47: 2 .

${ }^{23}$ Abū Muḥammad 'Abd al-Haq bin Ghālib bin 'Abd al-Raḥmān bin Tamām bin 'Ạtiyah al-Mahạaribi al-Shāhir bi Ibn 'Atiyyah, beliau lahir di Gharnaṭah Andalusia Spanyol pada tahun $481 \mathrm{H}$ dan wafat di Andalusia pada tahun $541 \mathrm{H}$. dari sisi madhab 
ayat tersebut turun kepada dua golongan yang berbeda. Yaitu ayat pertama turun kepada orang Makkah dan ayat kedua turun kepada Ahli Madinah. ${ }^{24}$

E. Informasi al-Qur'an tentang Nama Muhammad (Ahmad) yang telah Disebutkan oleh Para Nabi Terdahulu

Dalam surah al-Ṣaf [61]: 6, Allah berfirman:

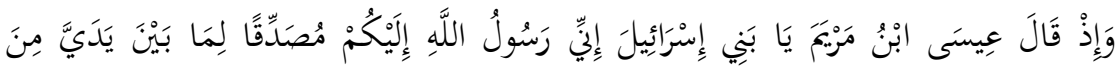

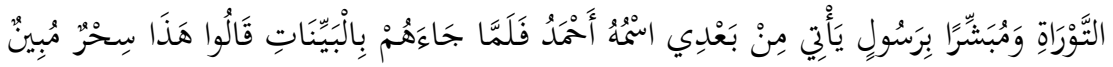

Dan ingatlah ketika Isa putera Maryam berkata "Wahai Bani Isra'īl, sesungguhnya aku adalah utusan Allah kepadamu, membenarkan kitab yang turun sebelumku, yaitu Taurat dan memberi kabar gembira dengan datangnya seorang rasul bernama Ahmad (Muhammad), maka tatkala rasul itu datang kepada mereka dengan membawa bukti-bukti yang nyata, mereka berkata ini adalah sibir yang nyata." 25

Ayat di atas memberikan informasi tentang kedatangan Aḥmad dalam kitab terdahulu, Taurat dan Injil. Ayat ini membutuhkan ilmu multidisipliner, sebab seorang mufasir harus mengkaji lebih dalam kitab Injil atau Taurat yang saat ini di klaim menjadi milik umat Kristen-Yahudi.

Seorang mufasir sufi yang wafat pada tahun $465 \mathrm{H}$ bernama alQushairi menjelaskan bahwa, sosok Muhammad telah di prediksikan

fikih beliau mengikuti al-Mālik, dan kitab tafsir beliau adalah al-Muharrar al-Wajiž Fī Tafsì al-Qur'an al-'Azizi.

${ }^{24}$ Abū Muḥammad 'Abd al-Haq bin Ghālib bin 'Abd al-Raḥmān bin Tamām bin 'Āṭyah al-Maḥāribi al-Shāhir bi Ibn 'Atiyyah, al-Muḥarrar al-Wajì̃. (al-Maktabah alShāmilah al-Iṣdār Thāni). QS. 47: 2.

${ }^{25}$ Departemen Agama Republik Indonesia, al-Qur'an dan Terjemahnya. QS. Al-Ṣaf [61]: 6. 
oleh semua nabi hingga nabi $\overline{\text { Issa as. }}{ }^{26}$ Sementara itu menurut Isma ${ }^{\bar{i}} 1$ Haqqi ayat di atas dikhususkan kepada Bani Isrāîl yaitu keturunan Nabi Ya'qub yang memprediksikan kedatangan nabi Muhammad saw. Pernah suatu ketika para murid nabi Isa as. bertanya kepadanya. 'Apakah setelah kami ada lagi umat?' 'Ya, nanti akan ada umat Muhammad, yang alim, takwa, dan berbuat baik. ${ }^{27}$

Senada dengan Ismāil Ḥaqqi, Ibnu Jazi menjelaskan bahwa akan ada umat setelah kalian (para umat Nabi Isa as) yaitu umat Ahmad yang menjadi ahli hikmah, hakim, lebih takwa dan berbuat baik. Sedangkan nama Aḥmad juga dijelaskan oleh Nabi bahwa ia juga memiliki lima nama, salah satunya adalah Aḥmad. ${ }^{28}$

Sedangkan menurut mufasir dari Irak sekaligus pernah menjabat sebagai hakim agungnya Abasiyah dikala itu yang bernama al-Māwardi menjelaskan bahwa ayat mengenai kedatangan Aḥmad ini memiliki dua tafsir. Pertama ia sebagai kabar gembira terhadap kedatangan dan agar iman kepadanya. Sedangkan yang kedua adalah sebagai bukti kemukjizatan prediksi nabi Isa as. Sehubungan dengan nama Aḥmad, al-Māwardi menjelaskan sebuah riwayat 'Nama saya di dalam Taurat adalah Aḥid, dalam Zabūr al-Māhi, dalam Injīl Aḥmad dan dalam al-Qur'an adalah Muhammad. ${ }^{29}$

F. Analisa

Al-Qur'an telah menjelaskan bahwa kedatangan nabi Muhammad sudah diramalkan oleh kitab-kitab terdahulu, baik dalam Taurat ataupun Injil. Kitab Taurat yang ada sekarang menjadi sebuah

26 'Abd al-Kāìm bin Hawāzin bin 'Abd Mālik al-Qushairi, Latậ'if al-Ishārāt (alMaktabah al-Shāmilah al-Ișdār Thāni). QS. Al-Ṣaf [61]: 6.

${ }^{27}$ Ismāīil Ḥaqqi al-Islāmubuli, Tafsìr Ḥaqqi (al-Maktabah al-Shāmilah al-Iṣdār Thāni), QS. Al-Ṣaf [61]: 6.

${ }^{28}$ Muḥammad bin Aḥmad bin Muhammad bin Jazi al-Kalbi al-Gharnaṭi al-Māliki, alTashīl Li'ulüm al-Tañìil (al-Maktabah al-Shāmilah al-Ișdār Thāni), QS. Al-Ṣaf [61]: 6.

29 Abū Hasan 'Ali bin Mụ̣ammad bin Habīb al-Māwardi, al-Nukat wa al-'Uyūn. Beirut: Dār al-Kutub al-'Ilmiyyah, 2012, vol. 5, 529. 
teka-teki besar dalam masalah keotentikannya, sebab sejarah mencatat Taurat Musa berulangkali dimusnahkan oleh para raja yang menguasai Bani Isrāīil. Namun dalam hal nubuwwat dalam Alkitab yang di klaim isinya adalah dari Taurat, maka penulis akan mencoba menguraikan misteri dibalik nubuwwat yang disembunyikan dalam Taurat, dalam hal ini Perjanjian Lama.

\section{Ismubü Aḷmād}

Sebuah nama seharusnya tidak boleh di terjemahkan, sehingga tidak menjadi keracauan dalam memberikan status orang tersebut. Karena Taurat dahulu adalah berbahasa Ibrani, maka Perjanjian Lama juga harus dikembalikan terlebih dahulu kepada bahasa aslinya yaitu Ibrani.

a. Dalam Kidung Agung 5:1630

Kidung Agung yang masih berbahasa Ibrani menyatakan: "Hikko mamittakim we kullo Muhammadim zebdoodeh wa zebraee baena Jarusalem."

Potongan ayat ini terambil dari Song of The Songs atau dalam Alkitab diistilahkan sebagai Kidung Agung, yang artinya sebagai berikut "Teramat manis tutur sapanya, ia adalah Muhammad, inilah kekasihku dan sahabatku. O puteri-puteri Yarusalem" Dalam ayat ini sangat jelas disebutkan nama Muhammad dengan tambahan "im" yang merupakan bentuk jamak untuk penghormatan. Kata 'Tuhan' dalam bahasa Ibrani berarti Eloh, dan apabila ditambahkan kata "im" maka menjadi Elohim, artinya bukanlah menunjukkan banyak, akan tetapi untuk penghormatan, li al-ta'dim ${ }^{31}$, sehingga artinya adalah Muhammad yang Mulia.

${ }^{30}$ Ahmad Deedat, CD I. Apakah Ada Penyebutan Mubammad dalam Bibel, Menit ke 7:25 sampai 08:30.

${ }^{31}$ Dalam al-Qur'an kata dengan bentuk penghormatan ini misalnya lafaẓ nạ̣nu. 
b. Akan datang Aḥmad bagi semua bangsa, Hagai 2:7

Semua bangsa akan Ku gemparkan dan akan datang Himdah untuk semua bangsa, sehingga Aku akan memenuhi rumah-Ku ini dengan keagungan, demikian firman-Ku, Tuhan semesta alam. Keagungan rumah baru itu akan lebih hebat daripada keagungannya dulu. Demikian firman Tuhan semesta alam. Dan tempat inilah Aku akan memberikan Syalom. Demikian firman Tuhan semesta alam.

Menurut Abdul Ahad Dawud, ${ }^{32}$ ketika ia melihat Bibel berbahasa Ibrani, redaksi yang digunakan adalah "Ve yavu bimdath kol haggoyim," yang secara literal berarti "maka kelak akan datang Himadah bagi semua bangsa" kata ini di ambil dari bahasa Arami, yaitu bahasa Ibrani kuno, aslinya bimd yang dilafalkan tanpa huruf mati berarti himid, dalam bahasa Ibrani berarti harapan yang besar; atau sesuatu yang selalu di kejar oleh manusia. Dalam bahasa Arab, kata ḅamida (حم) juga berasal dari akar kata yang sama, yang memiliki arti pujian atau yang terpuji.

Mengenai kata syalom dan syalama dalam bahasa Ibrani, serta kata salam dan Islam dalam bahasa Arab, semua ahli bahasa Semit mengetahui bahwa kata syalom dan syalam merupakan derivasi dari satu kata yang sama. Keduanya memunculkan arti kedamaian atau penyerahan diri. ${ }^{33}$

Aminah binti Wahab, janda Abdullah bin Abdul Munthalib telah memilihkan nama untuk puteranya yang yatim

32 Abdul Ahāe Dawūd adalah seorang mantan Pastur Katolik Roma untuk wilayah Kaldan, sedangkan nama aslinya adalah David Benjamin, B.D. beliau sangat kompeten dibidang bahasa yang umumnya tidak di kuasai oleh para penerjemah Bibel, dalam penelitiannya di buku ini, ia merujuk kepada Bibel berbahasa Arami. Ibrani, Latin dan Yunani. Padahal hanya sediakit orang yang mampu memehami Bibel berbahasa Latin, versi "Vulgate" yang resmi di akui oleh gereja Katolik. Lihat dalam sampul buku, Abdul Ahad Dawud, Muhammad In The Bible, (Jakarta: Almahira, 2009).

${ }^{33}$ Abdul Ahad Dawud, Muhammad In The Bible. Jakarta: Almahira, 2009, 4-7. 
dengan nama Muhammad. Sungguh nama itu merupakan kata yang baru pertama kali di kenal dalam sejarah manusia. ${ }^{34}$

2. Sifat-sifat nabi terahir

a. Ummi, Dalam Yesaya 29:12 disebutkan:

"Dan apabila kitab itu diberikan kepada seseorang yang tidak dapat membaca dengan mengatakan: baiklah baca ini," maka ia akan menjawab: aku tidak dapat membaca." ${ }^{35}$

b. Warna kulit

Dalam Song of Songs/ Kidung Agung pasal 5 ayat 10 menjelaskan My beloved is white and ruddy, the chiefest among ten thousand (kekasihku yang berkulit putih dan kemerah-merahan, pemimpin diantara sepuluh ribu (orang).

c. Nabi dari bangsa Arab Yesaya 21:13-17 menyebutkan :

Dalam kesukaran di tanah Arab kau menetap wahai kafilah. Datangkanlah air terhadap orang-orang yang kehausan wahai penduduk tanah Tayma. Cukupkanlah orang yang melarikan diri dengan rotinya. Sesungguhnya mereka melarikan diri dari pedang yang terhunus, busur-busur panah yang telah direntangkan, dan dari derita perang. Demikianlah firman Tuhan. Dalam satu tahun (seperti setahun bagi seorang penyewa) semua kemuliaan Qaidar akan runtuh, dan busurbusur yang tersisa di tangan para pahlawan Bani Qaidar akan tanggal.

${ }^{34}$ Dawud,6-8.

35 Seorang muslim maklum mengetahui bahwa nabi Muhammad adalah seorang yang ummi/buta huruf, untuk itu beliau tidak dapat membaca, juga sering di ucapkan ketika seseorang sedang do'a qunut "nabiyyi al-ummiyyi' / seorang nabi yang buta huruf. Sayyid Tanțawi menyebutkan sabab nuఇūl-nya ayat pertama surat al-'Alaq/Iqra' ini, yaitu riwayat Bukhari-Muslim dari Āishah ra. : ...Jibril berkata "bacalab" Nabi menjawab, "aku tidak dapat membaca!" Hal ini di ulanginya sampai tiga kali..., ini menunujukkan bahwa nabi adalah seorang yang ummi, Lihat, Sayyid Tanțawi, Tafsìr al-Wasit,, (CD. AlMaktabah al-Shāmilah al-Ișdār al-Thāni), Surat al-'Alaq (96) ayat 1. 


\section{Ulangan 33: 2}

Cahaya Tuhan akan datang dari Sinai lalu menyingsing untuk mereka dari Seir dan bersinar terang dari gunung Paran. Dan datanglah bersama 10.000 orang suci dan hukum di tangan kanannya .

Ayat-ayat ini (Yesaya 21:13-17 dan Ulangan 33:2) di klaim oleh para penganut Nasrani sebagai nubuwat yang terakhir, dan mereka mengklaimnya jatuh kepada Isa, namun perlu dicatat bahwa, di sini terdapat suatu kejanggalan apabila nubuwat itu tertuju kepada nabi Isa as. Sebab, sangat jelas bahwa nabi tersebut dari Arab. Sudah maklum diketahui bahwa Isa bukanlah bangsa Arab, akan tetapi dari Isra'il, dari sini nampak bahwa nubuwat itu tertuju kepada Muhammad, sebab dialah orang yang berasal dari tanah Arab. ${ }^{36}$

Nubuwat ini diperkuat lagi dalam kitab Ulangan 33:2 yaitu nabi tersebut dari Gunung Paran. Gunung Paran adalah gunung-gunung yang ada di Makkah, tiada satupun orangorang Isra'il yang memiliki hubungan dengan orang Paran, Siti Hajar dan puteranya Isma'il-lah yang melakukan perjalanan dari Sinai. Isma'il menikah dengan seorang gadis Mesir, dan dari anak pertama pasangan itula kemudian menduduki Gunung Paran. Ayat ini masih berlanjut, "dan datanglah bersamanya 10.000 orang suci dan hukum di tangan kanannya."

Muḥammad adalah keturunan Isma'il yang mana dalam satu kesempatan dalam hidupnya, mamasuki kota Makkah bersama 10.000 orang suci (beriman). Hal ini terjadi pada saat penakhlukan kota Makkah (fath makkah), nabi Muhammad saw. membawa orang yang beriman sebanyak $10.000 .{ }^{37}$

36 Abdul Ahad Dawud, Muhammad In The Bible, (Jakarta: Almahira, 2009), xxii-xxvi.

37 Kejadian 21:12. 
3. Nabi itu sepertimu (Musa)

Dalam Ulangan 18:18 disebutkan:

Aku akan membangkitkan seorang dari antara saudara mereka, seperti kamu (Musa) dan Aku akan meletakkan firman$\mathrm{Ku}$ di mulutnya, dan dia akan berkata kepada mereka semua yang Aku perintahkan kepadanya.

Kaum Nasrani meyakini ramalan ayat tersebut ditujukan kepada nabi Isa as. (Yesus) dengan dua kriteria, yaitu sama-sama nabi Allah yang diberi kitab suci dan sama-sama dari Isra'il, namun umat Islam menilainya sebagai sebuah nubuwat akan kedatangan Muhammad. Agar merasa adil penulis akan menguji kedua klaim tersebut.

Saudara bangsa Isra'il (keturunan Ibrahim melalui Ishak) adalah bangsa keturunan Isma'il. Yesus bukan orang yang dimaksud ayat di atas, karena termasuk bangsa Isra’il. Jika ayat ini ditujukan kepada Yesus, maka redaksinya harus diganti "seorang nabi di antara kamu sendiri". Muhammad yang seperti Musa, bukan Yesus.

\section{PERBANDINGAN MUSA}

Kelahiran

Berkeluarga

Kematian

Emigrasi

Melawan musuh

Kemenangan

Tulisan wahyu kepemimpinan
Biasa

Menikah, beranak

Biasa/normal

Ke Median

Dikejar

Moral-fisik

Saat hidupnya

Ditolak, diterima

\section{MUHAMMAD YESUS}

Biasa

Ajaib

Menikah, beranak Tidak menikah

Biasa/normal

Ke Madinah

Tidak biasa

Tidak

Dikejar dan perang Tidak

Moral-fisik

Tidak

Saat hidupnya

Setelah mati

lalu Ditolak,

diterima

lalu ditolak 
Spiritualis, vol. 4, no. 1, Maret 2018|67

\section{Kesimpulan}

Kedatangan nabi Muhammad saw. dengan telah diinformasikan oleh al-Qur'an bahwa nama dan sifat-sifatnya telah diramalkan oleh kitab-kitab kitab terdahulu. Kitab-kitab terdahulu seperti Taurat dan Injil, kini berada di tangan umat Kristen, yaitu Perjanjian Lama dan Perjanjian Baru. Ramalan tentang kedatangan nabi Muhammad lebih banyak dijelaskan oleh Perjanjian Lama, yaitu pada Yesaya 21:13-17 dari tanah Arab, 29:12 tentang nabi yang ummi, Ulangan 33:2 tentang asalnya dari Arab, 18:18 tentang sosok seperti nabi Musa, dan Hagai 2:7 tentang Ahmad bagi semua bangsa. 


\section{DAFTAR PUSTAKA}

'Abd al-Bāqi, Muhammad Fu'ad. Al-Mu'jam al-Mufahras li Alfäzal-Qur'àn al-Ažìm, Kairo: Dār al-Ma’àrif, 1119.

'Abd al-Hayy al-Farmawy, al-Bidāyah fì al-Tafsir al-Maudhü'i, Mesir: Maṭba'àt al-Haḍarāt al-'Arabiyah, 1977.

al-Baghawi, Al-Ḥusain bin Mas'ūd bin Muḥammmad bin al-Farā' alShāfi'i., Ma'ālim al-Tanæịil, al-Maktabah al-Shāmilah al-Iṣdār Thāni.

al-Bukhāri, Muḥammad bin Ismā̄il bin Ibrāhim bin al-Mughirah. alJämi’ al-Ṣahị̄, Kairo: Dār al-Shu'ab, 1987.

Dawud, Abdul Ahad. Muhammad In The Bible, Jakarta: Almahira, 2009.

Deedat, Aḥmad. The Choice, Jakarta: Pustaka Al-Kautsar, 1999.

Haekal, Husein. Sejarah Muḥammad saw. (Jakarta, Litera Antarnusa, 2011.

Ibn 'Ațiyah, Abū Muḥammad 'Abd al-Haq bin Ghālib bin 'Abd alRaḥmān bin Tamām bin 'Āṭiyah al-Maḥāribi al-Shāhir. alMuḥarrar al-Wajī̌, al-Maktabah al-Shāmilah al-Iṣdār Thāni.

Ibn Jāzi, Muḥammad bin Aḥmad bin Muḥammad bin Jazi al-Kalbi alGharnaṭi al-Māliki, al-Tashīl Li'ulum al-Tanæ̧il, al-Maktabah alShāmilah al-Iṣdār Thāni.

Ibn Kathīr, 'Imād al-DĪn Abū al-Fidā' Ismā'il bin 'Amr al-Bașri alQarshi al-Dimashqi. Tafsì al-Qur'an al-'Ażim, al-Maktabah alShāmilah al-Iṣdār Thāni. 
Ismā̄̄il Ḥaqqi al-Islāmubuli, Tafsìr Haqqi, al-Maktabah al-Shāmilah alIșdār Thāni.

Muhajir, Abu Mahmoud, Doktrin Gereja Kontra Bibel, Surabaya: Pustaka Da’i, 2002.

al-Māwardi, Abū Ḥasan 'Ali bin Muḥammad bin Ḥabīb. al-Nukat wa al'Uyūn, Beirut: Dār al-Kutub al-'Tlmiyyah, 2012.

al-Mujāhid, Abū al-Hajjaj Mujāhid bin Jabr al-Tābi’i al-Qarshi alMakhzūmi, Tafsìr Mujāhid, al-Maktabah al-Shāmilah al-Ișdār Thāni.

Naik, Zakir. Nama Muhammad dalam Kitab-kitab Suci, India: Islamic Researc Fundation, tt.

al-Qurțubi, Muḥammad bin Aḥmad bin Abi Bakr bin Farḥ Abū 'Abd Allāh. al-Jāmi' al-Abkäm al-Qur'an, al-Maktabah al-Shāmilah alIṣdār Thāni.

al-Qushairi, 'Abd al-Karim bin Hawāzin bin 'Abd Mālik. Latâ'í al Ishärāt, al-Maktabah al-Shāmilah al-Iṣdār Thāni.

Rohman, Abdur. Gender: Menyingkap Tabir Ketimpangan, Kediri: Parafrasa, 2015.

Islam Akan Menang: Analisa Kemenangan Islam di Masa Depan, Kediri, Parafrasa dan Santri Salaf Press, 2013.

----------, Tafsir Sababat: Fakta Sejarah Penafsiran al-Qur'an Ala Sababat Nabi, Kediri, Parafrasa, 2015. 
Spiritualis, vol. 4, no. 1, Maret 2018|70

Yunsabu ila al-Ṣahabahah 'Abd Allah Ibn 'Abbās, al-Miqbās min Tafsìr Ibn 'Abbās, al-Maktabah al-Shāmilah al-Iṣdār Thāni.

al-Samarqandi, Nasr bin Muhammad bin Ahmad. Baḥr al-Ulum, alMaktabah al-Shāmilah al-Iṣdār Thāni.

al-Zuhaili, Wahbah bin Muștafa. al-Tafsì al-Wasit, Damaskus: Dār alFikr, 1422. 